BIOMEDICAL AND BIOSOCIAL ANTHROPOLOGY
Official Journal of the International Academy
of Integrative Anthropology
journal homepage: htp://bba-journal.com

\title{
Palmar dermatoglyphics of modern Ukrainians: regional trends
}

\section{Gunas V. I. ${ }^{1}$, Mishalov V. D. ${ }^{2}$, Serebrennikova O. A. ${ }^{1}$, Klimas L. A. ${ }^{1}$, Shayuk A. V. ${ }^{3}$}

${ }^{1}$ National Pirogov Memorial Medical University, Vinnytsya, Ukraine

${ }^{2}$ National Medical Academy of Postgraduate Education named after P. L. Shupyk, Kyiv, Ukraine 3Zhytomyr Ivan Franko State University, Zhytomyr, Ukraine

\section{ARTICLE INFO}

Received: 30 March, 2018

Accepted: 26 April, 2018

UDC: $572.524 .12(477)$

\section{CORRESPONDING AUTHOR}

e-mail: freekozak1@gmail.com Gunas V. I.

\begin{abstract}
Strengthening of global migration processes, often accompanied by an increase in crime and an increase in the number of unidentified individuals, necessitates the expansion of the use of indirect identification methods. In our opinion, involving dermatoglyphic analysis in cases of unidentified persons would help in forensic medical identification of the ethno-territorial membership of an unknown person. The purpose of the work is to identify a taxonomic complex of features of palmar dermatoglyphics at the local level that allow differentiating the regional affiliation of men in Ukraine. The study of dermatoglyphics of 400 virtually healthy men from 5 administrative-territorial regions of Ukraine was conducted using the method of $\mathrm{H}$. Cummins and Ch. Midlo. Statistical processing of the results was carried out in the package "STATISTICA 6.1" using nonparametric methods. The set of signs of palmar dermatoglyphic was revealed, showing a high degree of heterogeneity between men from the following administrativeterritorial regions of the country: central and eastern (20.0\% of indicators), central and northern (16.9\% of indicators), northern and western (16.9\% of indicators), western and eastern (15.4\% of the indicators) regions of Ukraine. Men from the northern and eastern (6.2\% of the indicators), the south and west (6.2\% of the indicator) and the southern and eastern (7.7\% of the indicators) regions of Ukraine show a significant affinity for the features of palmar dermatoglyphics. In general, the high taxonomic value for intra-population differentiation of the local level have: the localization and saturation of the palm pattern, the size of the palm angles, the presence/absence of additional axial triads, the length of the segment $c-t$, the Cummins index.

Keywords: palmar dermatoglyphics, men, administrative-territorial regions of Ukraine, identification of the person.
\end{abstract}

\section{Introduction}

Since 1926, when Cummins proposed a new term "dermatoglyphics", two areas of studying papillary skin relief - fingerprinting, as the prerogative of criminology and dermatoglyphics, as the prerogative of anthropogenetics and medicine, began to develop independently. By studying the same object - skin patterns, criminologists relied on one of the basic characteristics of papillary skin, on its individuality, and clinicians and anthropogenetics - on the other, namely on its high level of inheritance, since the tasks solved by one and the other were different. Criminologists are dedicated to finding individual features of skin patterns for the purpose of identifying a person [6, 8], and physicians and anthropologists - to search for typological features that unite people into a group to reveal associations with diseases, ethno-racial diagnostics and a number of others [12, 16].

The distinction between dermatoglyphics and fingerprinting is, to some extent, conditional, as evidenced by recent trends in these areas of knowledge that demonstrate the interconnection of scientific approaches in obtaining the necessary results and effectively complement each other $[1,10,15,19,20]$.

Thus, the involvement of not only molecular genetic analysis, but also dermatological analysis is useful in cases of the need for indirect identification of a person through the establishment of blood affinity [5, 7, 9]. Such cases in forensic expert practice, until now, usually arose in cases of controversial parenting, motherhood, substitution, loss, kidnapping of children, the establishment of persons who lost memory $[2,17,18]$ Today, more and more people live outside of their country of origin. Refugees, labor and political migrants, migrants due to racial discrimination and other reasons today account for $3 \%$ of the world's population [21]. 
Therefore, indirect identification of an individual is actualized by an increasing flow of illegal migrants who, in search of better luck and safe haven, often perish, and corpses are depersonalized as a result of their harmful factors and the development of corporal phenomena and become unidentified. In addition, illegal migration is often associated with an increase in economic and violent crime, accompanied by drug trafficking, human trafficking and terrorist acts, which also causes the need for indirect identification of a person. In our opinion, the creation of dermatological maps of donor countries and recipient countries with the detection of their regional features of dermatoglyphics would help in the forensic medical identification of the ethno-territorial membership of an unknown person.

The purpose of the work is to identify a taxonomic complex of features of palmar dermatoglyphics at the local level that allow differentiating the regional affiliation of men in Ukraine.

\section{Materials and methods}

400 prints of hand of healthy men aged 19 to 35 years old in the third generation inhabitants of 5 administrativeterritorial regions of Ukraine were investigated: 72 from the northern (Chernihiv, Kyiv, Sumy and Zhytomyr regions), 47 from the south (Autonomous Republic of Crimea, Kherson, Mykolaiv, Odesa and Zaporizhian regions), 165 from the central (Cherkasy, Dnipropetrovsk Kirovograd, Poltava and Vinnytsia regions), 45 from the eastern (Donetsk, Kharkiv, and Lugansk regions), 71 from the western (Chernivtsi, Ivano-Frankivsk, Khmelnytskyi, Lviv, Ternopil, Rivne, Volyn, and Zakarpattia regions) regions of the country. The study was conducted with the help of a special questionnaire, an analysis of medical and social factors of living conditions, which indicated a fairly high homogeneity of samples of somatic healthy men from different regions of Ukraine [14].

Bioethics Committee of National Pirogov Memorial Medical University, Vinnytsya found that the research carried out did not contradict the basic bioethical norms of the Helsinki Declaration, the Council of Europe Convention on Human Rights and Biomedicine (1977), the relevant provisions of the WHO and the laws of Ukraine (Minutes № 8 of 10.09.2013).

The dermatological study was performed according to H. Cummins and Ch. Midlo method [3]. Handprints were obtained using a printing ink on a sheet of paper [4]. The analysis was subject to 65 indicators of palmar dermatoglyphics, of which 32 indicators were qualitative and 33 indicators related to quantitative characteristics. Statistical processing of the obtained results was carried out in the package "STATISTICA 6.1" using nonparametric methods.

\section{Results}

Between healthy men the northern and southern regions of Ukraine, the following significant or trends difference indicators palmar dermatoglyphics are established: among quality indicators - in male from northern region more than in men of the southern region, the percentage of available pattern in II interdigital gap of right hand $(68.1 \%$ vs $51.1 \%, p$ $=0.065$ ); among quantitative indicators - in the northern region men larger than in men of the southern region, the value of palmar account comb a-b (39.32 \pm 5.68 against 36.965 .88 combs, $\mathrm{p}<0.05)$, and lower value palmar angle $\angle$ ctd of right hand (14.41 \pm 2.82 vs. $15.76 \pm 3.38, p<0.05)$; among the asymmetry of qualitative and quantitative indicators - in male of northern region greater than in men of the southern region, the value of the asymmetry of the presence pattern in the I $(97.2 \%$ vs. $89.4 \%, p=0.079)$ and II ( $93.1 \%$ vs. $80.9 \%, p<0.05)$ interdigital intervals and less absolute value of the asymmetry of the angle $\angle$ atd $(-0.294 \pm 2.699$ vs. $0.977 \pm 3.391, p<0.05)$ - asymmetry, on the contrary, is left-sided; angle $\angle$ dat $(0.042 \pm 4.251$ vs. $1.787 \pm 6.100, p=0.056)$ - asymmetry, in contrast, right-hand side; comb account a-b (1.125 \pm 4.488 against $-2.021 \pm 4.816$ combs, $p<0.001)$ - asymmetry, in contrast, sided comb account c-d $(-1.206 \pm 5.363$ against $1.860 \pm 7.649$ combs, $p<0.05)$ asymmetry, in contrast, left-handed.

Between practically healthy men of the northern and central regions of Ukraine, the following reliable or trends of the differences in palmar dermatoglyphic indices are established: among the qualitative indicators - in men of the northern region, the percentage of the presence of a pattern in the IV interdigital gap of the left hand is lower $(76.4 \%$ vs. $86.7 \%, p=0.050)$, and also on the left hand thenar $(62.5 \%$ vs. $74.5 \%, p=0.063)$ and on the both right $(75.0 \%$ vs. $85.5 \%$, $p=0.053)$ and left hypothenar $(73.6 \%$ vs. $83.6 \%, p=0.075)$ then in men from central region; among the quantitative indicators - in men of the northern region higher than in men of the central region, the value of the palm angle $\angle$ atb of the left hand $(16.60 \pm 2.75$ against $15.88 \pm 2.78, p=0.070)$ and the lower value of the right hand angle $\angle \mathrm{ctd}(14.41 \pm 2.82$ against $15.44 \pm 2.91, p<0.05)$, as well as the comb account of the $c-d$ right hand $(34.19 \pm 6.94$ versus $37.25 \pm 5.57$ combs, $p<0.001)$; among asymmetry of qualitative and quantitative indicators - among asymmetry of qualitative indicators of reliable or trends of differences are not established; among the asymmetry of the quantitative indices in men in the northern region is less than in men of the central region, the absolute value of the angle asymmetry $\angle$ atd $(-0.556 \pm 3.885$ vs. $0.933 \pm 4.442, p<0.05)$ - asymmetry, on the contrary, is leftsided; the angle $\angle$ ctd $(-0.294 \pm 2.649$ vs. $0.887 \pm 2.893, p<0.01)$ - asymmetry of the left-hand side, as well as the comb account c-d $(-1.206 \pm 5.363$ versus $2.197 \pm 5.663$ comb, $p<0.001)$ - the asymmetry is left-sided and higher value of the asymmetry of the comb account $a-b(1.125 \pm 4.448$ vs. $0.612 \pm 5.099$ comb,$p<0.05)$ is the asymmetry of the righthand side.

Between the practically healthy men of the northern and western regions of Ukraine, the following reliable or trends of the differences in palmar dermatoglyphic indices are established: among the qualitative indicators - in men of the northern region, the percentage of the presence of the pattern in the II interdigital gap of the right hand is higher $(68.1 \%$ vs. $53.5 \%, p=0.076$ ) and the simultaneous presence of several 
palmar axial triradius of the left hand ( $8.3 \%$ vs. $1.4 \%$, $\mathrm{p}=0.057$ ); among the quantitative indicators - in men of the northern region less than men in the western region, the value of the right-hand palmar angel $\angle$ ctd $(14.41 \pm 2.82$ against 15.43 $\pm 2.86, p<0.05)$, comb count of right hand $c-d$ (34.19 \pm 6.94 versus $36.165 .46 \mathrm{comb}, p=0.066)$ and greater comb account of the $c-d$ of the left hand $(35.57 \pm 6.33$ versus $33.31 \pm 7.50$ combs, $p=0.060)$; among asymmetry of qualitative and quantitative indicators - among asymmetry of qualitative indicators of reliable or trends of differences are not established; among the asymmetry of quantitative indices in men in the northern region is less than in men in the western region, the absolute value of the asymmetry of the angle $\angle$ atd $(-0.556 \pm 3.885$ vs. $1.169 \pm 4.802, p<0.05)$, the angle $\angle$ ctd $(-0.294 \pm 2.649$ vs. $0.970 \pm 3.225, p<0.05)-$ asymmetry of the left-hand side; angle dat $(0.042 \pm 4.251 \mathrm{vs}$. $-1.465 \pm 5.187, p=0.059)$ - right-hand asymmetry; the comb account $c-d(-1.206 \pm 5.363$ versus $2.833 \pm 5.656$ comb, $p<0.001)$ - right-side asymmetry, as well as the greater absolute value of the comb account $a-b(1.125 \pm 4.488$ versus $-0.348 \pm 3.682$ comb, $p<0.05)$ - right-side asymmetry.

Between the practically healthy men of the northern and eastern regions of Ukraine, the following reliable or tendencies in the differences in palmar dermatoglyphic indices are established: among the qualitative indicators in men of the northern region, the percentage of the presence of a pattern in the II intercostal space of the right hand is higher $(68.1 \%$ vs. $46.7 \%, p 0.05)$ and there is no central axial triradius of the left hand ( $0 \%$ vs. $4.4 \%, p=0.050)$; among the quantitative indicators - in men of the northern region it is higher than men in the eastern region, the value of the palm angle atd of left hand $(40.72 \pm 5.79$ against $38.91 \pm 4.50$, $\mathrm{p}=0.078$ ); among asymmetry of qualitative and quantitative indicators - among asymmetry of qualitative indicators of reliable or trends of differences are not established; among the asymmetry of quantitative indicators in men in the northern region, established lover than that of men in the eastern region, the absolute value of the asymmetry of the comb account a-b (1.125 \pm 4.488 vs. $-1.156 \pm 4.205$ comb, $p$ $<0.05)$ - asymmetry is right-hand side.

Between the practically healthy men of the southern and central regions of Ukraine, the following reliable or tendencies of the differences in the indicators of palmar dermatoglyphics are established: among the qualitative indicators - in men of the southern region, the percentage of the presence of a pattern in the II interdigital gap as the right one is lower $(51.1 \%$ vs. $72.1 \%, p<0.01)$ both and left $(53.2 \%$ vs. $70.3 \%, p<0.05)$ hand and palmar pattern in the left hand thenar area $(55.3 \%$ vs. $74.5 \%, p<0.05)$ and there is central axial triradius of the left hand $(2.1 \%$ vs. $0 \%, p=0.064)$; among the quantitative indicators - males in the southern region have lower than men in the central region Cummins index $(7.766 \pm 1.722$ versus $8.544 \pm 2.220, p<0.05)$; among asymmetries of qualitative and quantitative indicators - in men of the southern region more than in men of the central region, the value of asymmetry in the presence of central axial triradius $(2.1 \%$ vs. $0 \%, p=0.063)$ and less - by the presence of a palm pattern in the II interdigital gap $(80.9 \%$ vs. $91.5 \%, p<0.05)$ and in the hypothenar region $(85.1 \%$ versus $93.3 \%, p=0.077)$, as well as more pronounced asymmetry of the Cummins index $(1.891 \pm 1.8665$ vs. $1.163 \pm 1.890, p<0.05)$.

Between the practically healthy men of the southern and western regions of Ukraine, the following reliable or tendencies of the differences in palmar dermatoglyphic indices were established: among the qualitative indicators in men of the southern region, the percentage of the presence of a pattern in the hypothenar region is higher than that of men in the southern region $(83.0 \%$ versus $66.2 \%, p<0.05)$; among the quantitative indicators, men in the southern region have lower than men in the western region, the value of the comb account $a-b$ of the right hand $(36.96 \pm 5.88$ versus $39.15 \pm 5.29$ combs, $p<0.05$ ); among the asymmetries of qualitative and quantitative indicators - in men of the southern region more than men in the western region, the value of asymmetry in the presence of a pattern in the area thenar (97.9\% vs. $88.7 \%, p=0.068)$, as well as comb account $a-b$ ($2.021 \pm 4.816$ vs. $-0.348 \pm 3.682$ combs, $p<0.05$ ).

Between the practically healthy men of the southern and eastern regions of Ukraine, the following reliable or tendencies of the differences in palmar dermatoglyphic indices are established: among qualitative indicators reliable or trends of differences are not established; among the quantitative indicators - in the men of the southern region higher than in the men of the eastern region, the value of the palm angle atd $(41.19 \pm 6.03$ vs. $38.82 \pm 4.87, p<0.05)$ and smaller - the angle of the right hand dat $(55.96 \pm 7.20$ vs. $59.60 \pm 6.44, p<0.05)$, as well as the length of the segment ct of the right hand $(80.95 \pm 10.90$ vs. $84.86 \pm 8.18 \mathrm{~mm}, \mathrm{p}=0.065)$; among the asymmetries of qualitative and quantitative indicators - in men of the southern region higher than in men of the eastern region, the value of asymmetry in the presence of a pattern in the thenar region $(97.9 \%$ vs. $88.9 \%$, $p=0.083)$ and the absolute value of the asymmetry of the angle ctd $(0.977 \pm 3.391$ against $-0.333 \pm 3.405, p=0.079)$ asymmetry, by contrast is right-hand side.

Between the practically healthy men of the central and western regions of Ukraine, the following reliable or tendencies of the differences in the indicators of palmar dermatoglyphics are established: among the qualitative indicators - in men of the central region, the percentage of the presence of a pattern in the II interdigital gap as the right one $(72.1 \%$ versus $53.5 \%$, $p<0.01)$, and left $(70.3 \%$ vs. $56.3 \%, p<0.05)$ hands and in the III interdigital gap of the left hand $(95.8 \%$ vs. $88.7 \%, p<0.05)$, as well as a higher percentage of the presence of the pattern on the hypothenar as the right one $(85.5 \%$ vs. $66.2 \%, p<0.001)$ and left $(83.6 \%$ vs. $69.0 \%, p<0.05)$ hands and on the thenor both right $(69.7 \%$ vs. $57.7 \%, p=0.075)$ and left $(74.5 \%$ vs. $62.0 \%, p=0.054)$ hands; among quantitative indicators reliable or trends of differences are not established; among the asymmetries of qualitative and quantitative indicators - in men of the central region higher than in men of the western 
region, the value of asymmetry in the presence of a pattern in the IV interdigital gap $(94.5 \%$ vs. $85.9 \%, p<0.05)$ and less values of the asymmetry of the comb account b-c $(0.306 \pm 4.022$ versus $1.727 \pm 3.661$ combs, $p<0.05)$.

Between the practically healthy men of the central and eastern regions of Ukraine, the following reliable or trends of the differences in palmar dermatoglyphic indices were established: among the qualitative indicators - in men of the central region, the percentage of the presence of the pattern on the thenar as the right one $(69.7 \%$ vs. $55.6 \%, p=0.077)$, and left $(74.5 \%$ vs. $60.0 \%, p=0.058)$ hands, in the I interdigital gap of the right hand $(28.5 \%$ vs. $15.6 \%, p=0.080)$, in the II interdigital gap as the right one $(72.1 \%$ vs. $46.7 \%, p<0.01)$, and left $(70.3 \%$ vs. $53.3 \%$, $p<0.05)$ hands, absent (as opposed to east) additional central axial triradius of left hand ( $0 \%$ vs. $4.4 \%, p<0.01$ ); among the quantitative indicators, men in the central region have smaller than men in the eastern region, the value of the palm angle $\angle$ dat of the right hand $(57.49 \pm 6.17$ versus $59.60 \pm 6.44, p<0.05)$, and the greater significance of the left hand index of Cummins $(8.544 \pm 2.220$ versus $7.795 \pm 2.205, p<0.05)$; among the asymmetry of qualitative and quantitative indicators - in men of the central region higher than men in the eastern region, the value of asymmetry in the presence of a pattern in the IV interdigital interval $(94.5 \%$ vs. $86.7 \%, p=0.074)$, the absolute value of the asymmetry of the palm comb account $c-d(2.197 \pm 25.663$ versus $-0.452 \pm 5.388$ comb, $p=0.076$ ) and the absolute value of the asymmetry of the angle $\angle$ ctd $(0.887 \pm 2.893$ vs. $-0.333 \pm 3.405, p<0.05)$, as well as the less absolute value of the asymmetry of the angle $\angle$ atd $(0.933 \pm 4.442$ vs. $-1.067 \pm 6.517, p<0.05)$ is the asymmetry of the right-hand side and the angle $\angle$ atb ($0.103 \pm 2.318$ vs. $-1.111 \pm 3.284, p<0.05$ ).

Between the practically healthy men of the western and eastern regions of Ukraine, the following reliable or trends of the differences in palmar dermatoglyphic indices were established: among the qualitative indicators - in men of the western region, the percentage of the pattern on the hypothenar of the right hand $(66.2 \%$ versus $82.2 \%, p=0.063)$ and there is no (in contrast to the east) additional central axial triradius on the left hand ( $0 \%$ vs. $4.4 \%, p=0.077$ ); among the quantitative indicators - men in the western region have more higher than the men of the eastern region, the value of the palm angle $\angle$ atd $(41.35 \pm 5.46$ vs. $38.82 \pm 4.87, p<0.05)$ and the angle $\angle$ atb $(16.44 \pm 2.69$ versus $15.24 \pm 2.47, p<0.05)$ of the right hand and less than that of men in the eastern region, the value of the palm angle $\angle$ dat $(56.90 \pm 5.74$ vs. $59.60 \pm 6.44, p<0.05)$ and the length of the segment $c$ - $t$ $(80.84 \pm 10.47$ vs. $84.86 \pm 8.18 \mathrm{~mm}, p<0.05)$ of the right hand; among the asymmetries of qualitative and quantitative indicators, men in the western region have more than men in the eastern region, the value of the comb account c-d $(2.833 \pm 5.656$ vs. $0.452 \pm 5.388$ comb, $p<0.05)$, as well as the absolute value of the angle asymmetry $\angle$ atd $(1.169 \pm 4.802$ against $-1.067 \pm 6.517, p<0.05)$ - asymmetry, in contrast, right-hand side; angle $\angle$ ctd $(0.970 \pm 3.225$ vs. $0.333 \pm 3.406, p<0.05)$ - the asymmetry, in contrast, is right- hand side and the smaller - angle $\angle$ atb $(-0.127 \pm 2.311$ vs. $1.111 \pm 3.284, p=0.061)$.

\section{Discussion}

Thus, on the basis of the analysis of indicators of palmar dermatoglyphics, administrative-territorial regions of Ukraine were identified both with significant and minor differences between them. (Fig. 1).

High heterogeneity is established on the basis of qualitative and quantitative indicators of palmar dermatologic signs among the following administrative-territorial groups: between the inhabitants of the central and eastern regions ( $20.00 \%$ of the indicators), as well as the central and northern (16.92\% indicators), western and northern $(16.92 \%$ of indicators) and western and eastern (15.38\% of indicators) of Ukrainian regions. That is, the vector of distinctions on the basis of palmar dermatoglyphics lies through the central regions of Ukraine to the east, north and west of the country (see Fig. 1).

It should be noted that according to the results of our previous study [11] men, residents of the listed regions (except central and northern), show heterogeneity also on the basis of finger dermatoglyphics: central and eastern $20.37 \%$ of indicators, northern and western - $16.67 \%$ indicators, western and eastern $-12.04 \%$ of indicators.

The differences in the structure of palmar comb skin of the central region of Ukraine from such an eastern one consists in the more frequent patterning of the thenar, the I and II interdigital intervals of both hands, in the higher values of the Cummins index and the absence (as opposed to the east) of the additional central axial triadius on the left brush, lower values of the $\angle$ dat angle of the right hand. Differences in the asymmetry of the angles $\angle$ atd and $\angle \mathrm{ctd}$, which are characterized by the rightside predominance of values in contrast to the eastern region, where the left-hand side predominates, as well as the less lefthanded predominance of the angle $\angle$ atb values, which is less pronounced than in the east.

For palmar dermatoglyphics of the central region of Ukraine, which distinguishes it from this northern region are

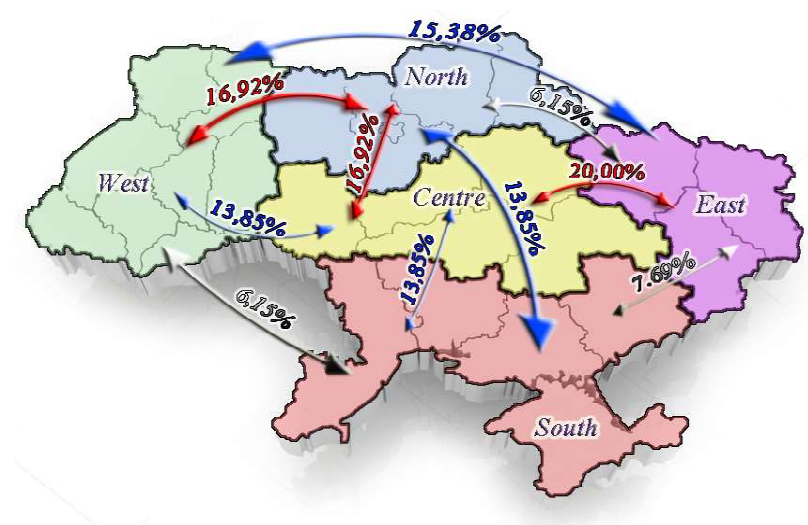

Fig. 1. Distribution of differences of administrative-territorial regions of Ukraine on the basis of palmar dermatoglyphics. 
characterized by: more frequent patterning of the hypothenar of both hands, as well as the thenar and the IV interdigital gap of the left hand, the smaller values of the angle $\angle$ atb of the left hand and the larger values of the angle $\angle$ ctd and length $c-d$ of right hand. Differences in the asymmetry of the $\angle$ atd and $\angle$ ctd angles and the comb account $c-d$, which are characterized by the right-hand side of the values unlike the northern region where the left-hand side predominates, and the left-hand side of the values of the comb account $a-b$, in contrast to the northern region, are noted.

At the same time, according to the results of the previous study [11], men, residents of the northern and central regions of Ukraine, in terms of qualitative and quantitative indicators of signs of digital dermatoglyphics, exhibit significant homogeneity (differences are recorded at $6.48 \%$ of the indicators).

The distinguishing features of palmar dermatoglyphics for the attribution of men to the western or northern regions of Ukraine are the pattern in the II interdigital gap and the simultaneous presence of several axial triadiosis of the left hand, which is less common in men of the western region, with the size of the angle $\angle$ ctd and the comb account $c-d$ of the right hand is bigger, and the c-d of left hand is smaller. Differences in the asymmetry of the angles $\angle$ atd, $\angle$ ctd and c- $d$ counts are marked, which are characterized by a rightside predominance of values in contrast to the northern region where the left-hand side predominates, as well as in the index of the left-hand side asymmetry of the angle $\angle$ dat, unlike the northern region, where the right-side predominance is fixed.

For palmar dermatoglyphics of the western region of Ukraine, which distinguishes it from such an eastern region, is characterized by: less frequent patterning of the hypothenar, there is no simultaneous presence of several axial triradius of the left hand, larger values of the corners $\angle$ atd and $\angle$ atb of the right hand, smaller values of the angle $\angle$ dat, and the length of the segment $\mathrm{c}$-t right hand. For the values of the corners $\angle$ atd and $\angle$ ctd in the western region is characteristic right-side, and in the east - the left-handed predominance, as well as more pronounced right-hand asymmetry of the comb account c-d.

A slightly smaller number of differences in the signs of palmar dermatoglyphics are established between men, residents of central and western (13.85\% of indicators), central and southern (13.85\% of indicators), as well as northern and southern $(13.85 \%$ of indicators) regions of Ukraine (see Fig. 1).

For palmar dermatoglyphics of men of the central region of Ukraine, which distinguishes it from such a western region, is characterized by: more frequent presence of the palmar pattern in the hypothenar, thenar and in the II interdigital gap of both hands, as well as in the III interdigital gap of the left hand. In men of the central region, the asymmetry in the presence of a pattern in the IV interdigital interval is more pronounced, and the value of the comb account b-c is less pronounced.
For the palmar dermatoglyphics of the central region of Ukraine, distinguishing it from such a southern region is characterized by: higher values of the Cummins index of the left hand, more frequent presence of the palmar pattern in the area of the left hand and in the II interdigital gap of both hands. In representatives of the central region, unlike the inhabitants of the southern region, we do not meet the central axial triradius on the left hand. There are differences in asymmetry indices: more pronounced in men in the central region - for the presence of a pattern in the II interdigital gap and in the hypothenar region and less pronounced - for the Cummins index.

Distinguishing features palmar dermatoglyphics to assign men or to the north or to the south of the region is a pattern in the II interdigital gap of right hand that male of northern region is more common and palmar comb expense $a-b$ of right hand that in male of northern region is larger at the same time the value of the palm angle $\angle \mathrm{ctd}$ in them is smaller. In the northern region men more often than in men of the southern region, the asymmetry is manifested by the presence of a pattern I and II interdigital intervals, less often evident asymmetry of angle $\angle$ atd and comb account c-d, asymmetry of which, by contrast, left-sided and angle $\angle$ dat and comb account a-b, the asymmetry of which, on the contrary, is right-sided.

It should be noted that from the above-mentioned regions palmar dermatoglyphics of men of the central administrativeterritorial region is the most different from all other regions. By its very nature, it corresponds to the central dermatological complex, which has been isolated by S. P. Segeda [13], but the indices have greater absolute values. Palmar dermatoglyphics is characterized by the most "western" combination of dermatological features: medium-high Cummins index and high frequency of patterns on the hypothenar. We will add that according to the data we have received, the frequency of patterns on the thenar and in the II and III interdigital intervals is also high.

Significant homogeneity was found on qualitative and quantitative indicators of palmar dermatoglyphics, characteristic of men, residents of southern and western (6.15\% of indicators), northern and eastern $(6.15 \%$ of indicators) and southern and eastern (7.69\% of indicators) regions Ukraine, which gives grounds for evaluating them within the specified territorial boundaries as genetically related (see Figure 1).

It should be noted that according to the results of the previous study [11] men, residents of the southern and western regions of the country, show a similarity also on the basis of finger dermatoglyphics $(9.26 \%$ of indicators of only qualitative characteristics).

Differences in the structure of the palmar comb skin of the southern region of Ukraine from such a western one is in the more frequent pattern of the hypothenar and lower values of the comb account $a-b$ of the right hand, and the presence of patterns in the area of the thenar and the values of the comb account $a-b$ shows a more pronounced asymmetry. 
The distinguishing features of palmar dermatoglyphics for the attribution of men to the northern or eastern regions are more frequent patterning of the II interdigital gap of the right hand, the absence of central axial triradius on the left hand and the greater value of the palm angle $\angle$ atd of the left hand in the men of the northern region compared with the eastern region. They have a right-side asymmetry for the comb account $a-b$.

For the palmar dermatoglyphics of the southern region of Ukraine, which distinguishes it from such an eastern region, is characteristic: the greater values of the palm angle $\angle$ atd and smaller are dat angle and the length of the c-t segment of the right hand, more often, asymmetry appears in the presence of a pattern in the thenar region, and the right side - the angle $\angle \mathrm{ctd}$.

We note that simultaneously both the systems of dermatoglyphic (both finger and palm) genetic affinity show the southern and western regions, and heterogeneity - the central and eastern, northern and western, western and eastern regions of the country.

According to the data of S.P. Segeda [13], the results of the geographical and correlation analysis of the system of dermatoglyphics indicate a gradual strengthening of the South-Europe component from the North to the South-West, South and Southeast of Ukraine, which is confirmed by our data. The results obtained regarding the homogeneity of the signs of dermatoglyphics in the southern, western, northern, and eastern and southern and eastern regions of Ukraine, in our opinion, are the result of an intensive population mix within these territorial boundaries and reflect the state policy of the previous decades in the field of regulation of internal migration of the population. The pre-epoch was characterized by the organized interregional movement of people and labor force from other regions of the republic which were directed, mostly from the western region, to agricultural enterprises in the south of Ukraine and from the north to industrial centers of the east.

Thus, signs of dermatoglyphics preserve their information capabilities in a rather long time, for many generations, making it possible to determine the degree of genetic affinity of the population of certain regions of the country, the magnitude of which depends on the intensity of migration

\section{References}

[1] Bogchenko, A., Popov, V., \& Zaslavskiy, G. (2008). Dermatoglyphic at identification. St. Petersburg: Legal Center Press. ISBN 978-5-94201-561-9.

[2] Bose, P. K., \& Kabir, M. J. (2017). Fingerprint: A Unique and Reliable Method for Identification. Journal of Enam Medical College, 7(1), 29-34. doi: http://dx.doi.org/10.3329/ jemc.v7i1.30748

[3] Cummins, H., \& Midlo, Ch. (1961). Finger Prints, Palms and Soles. An Introduction to Dermatoglyphics. Philadelphia.

[4] Gladkova, T. D. (1966). Skin patterns of the hand and foot of monkeys and humans. M.: Science. https://www.twirpx.com/ file/1246327/

[5] Greely, H. T., \& Kaye, D. H. (2013). A brief of genetics, genomics and forensic science researchers in Maryland v. King. processes, the ratio of indigenous and populated population, as well as the ethnicity of the incoming population in one or another region of the country.

\section{Conclusion}

1. There is a high phenotypological heterogeneity of qualitative and quantitative indicators of palmar dermatoglyphic for a number of administrative-territorial groups: between the inhabitants of central and eastern (20.0\% of indicators), central and northern $(16.9 \%$ of indicators), northern and western (16.9\% of indicators), western and eastern (15.4\% of indicators), regions of Ukraine

2. For regions with high heterogeneity of the signs of palmar dermatoglyphics, their complexes have been selected, which can be used to diagnose the regional membership of men: for the central and eastern regions it is the patterning of the hypothenar, thenar, I and II interdigital interval, the size of the $\angle$ dat angle, the index of Cummins, the additional axial triradius; central and northern - the patterning of the hypothenar, the thenar and the IV interdigital gap, the size of the corners $\angle$ atb and $\angle$ ctd and the comb account c-d; northern and western - the patterning of the II interdigital gap, the additional axial triradius, the size of the angle $\angle$ ctd and the comb account c-d; western and eastern - patterning of hypothenar, additional axial triradius, angular size $\angle$ atd, $\angle$ atb and $\angle$ dat, length of segment c-t.

3. Significant homogeneity was revealed in terms of qualitative and quantitative indicators of palmar dermatoglyphics, typical for men, residents of northern and eastern $(6.2 \%$ of indicators), south and west $(6.2 \%$ of indicators) and southern and eastern (7.7\% of indicators) regions of Ukraine

4. Among the signs of palmar dermatoglyphics, the high taxonomic value for intrapopulation differentiation of regions with low heterogeneity has the following dermatoglyphic complexes of features: for northern and eastern - patterning of the II interdigital gap, the additional axial triradius and the size of the angle $\angle$ atd; southern and western - patterning of hypothenar and comb account a-b; southern and eastern the size of the palm corners $\angle$ atd and $\angle$ dat, the length of the segment c-t.

Jurimetrics, 54(1), 43-45. https://www.jstor.org/stable/ 24395578

[6] Kurbanov, A. T., Karataeva, L. A., \& Nizomhozaeva, Sh. B. (2016). Dermatoglyphics in forensic medicine. Web of Scholar 7(7), 6-7. https://www.webofsholar.com/

[7] Lennard, C. J., Champod, C., Margot, P., \& Stoilovic, M. (2016). Fingerprints and other ridge skin impressions. CRC press. ISBN 9781498728935 - CAT\# K25943

[8] Mazur, E. S. (2015). Possibilities of dermatoglyphics methods in criminalistics research of external signs of human. Bulletin of Tomsk State University, 390, 141-145. doi: 10.17223/ 15617793/390/24

[9] Mazur, E. S., \& Ivanov, I. V. (2016). The possibility of using special knowledge in the detection and investigation of crimes. 
Criminal Justice, 1(7), 121-126.

[10] Mazur, Ye. S. (2014). Dermatoglyphics in personality research: forensic and medico-legal aspects. Tomsk: Publishing House of Tomsk State University. https://www.twirpx.com/file/1758515/

[11] Mishalov V. D., Serebrennikova O. A., Klimas L. A., \& Gunas V. I. (2018). Regional trends indicators finger dermatoglyphics among modern Ukrainians. Biomedical and biosocial anthropology, 30, 5-12.

[12] Rivalderia, N., Gutierrez-Redomero, E., Alonso-Rodriguez, C., Dipierri, J. E., \& Martin, L. M. (2017). Study of fingerprints in Argentina population for application in personal identification. Science \& Justice, 57(3), 199-208. doi: 10.1016/ j.scijus.2017.02.004

[13] Segeda, S. P. (2001). Anthropological composition of the Ukrainian people: ethnogenetic aspect. Publishing house named after Olena Teliha.

[14] Shinkaruk-Dykovytska, M. M. (2012). Medical and social factors of living conditionsof somatic healthy men from various natural and administrative regions of Ukraine. Biomedical and biosocial anthropology, 19, 248-254.

[15] Sidorenko, A. G., Mazur, Ye. S., \& Zvyagin, V. N. (2005). About the medical and forensic method of fixing the ridge counting of the palmar surface of the hands, based on the topography of the arrangement of triradius and large palmar folds. Current Issues of the Theory and Practice of Forensic Medical
Examination: Collected Works Krasnoyarsk, 3, 137-138.

[16] Xue, W., Han, W., \& Zhou, Z. S. (2013). ADAM33 polymorphisms are associated with asthma and a distinctive palm dermatoglyphic pattern. Molecular medicine reports, 8(6), 1795-1800. doi: 10.3892/mmr.2013.1733

[17] Yarovenko, V. V. (2013). Dermatogyphic peculiarities of the personality in the context of crime determination. All-Russian Journal of Criminology, 4(1), 36-40.

[18] Yefremov, I. S., Chistikina, T. A., \& Chistikin, A. N. (2016). Propensity to aggression and dermal patterns. Forensic Medicine, 3, 20-22. doi: 10.19048/2411-8729-2016-2-3-20-22

[19] Zvyagin, V. N. (2002). Dermatoglyphics in forensic medicine. Papillary patterns: identification and characterization of personality (fingerprinting and dermatoglyphics), 81-112. https://www.twirpx.com/file/984935/

[20] Zvyagin, V. N., Sidorenko, A. G., Kladov, S. Yu., \& Mazur, Ye. S. (2007). Forensic medical identification using dermatoglyphic features of the palms. The publication is presented in the materials of the All-Russian scientific-practical conference "Modern problems of applying new technologies in the detection and investigation of crimes", Tomsk (pp. 3840). Tomsk: [w.p.].

[21] Zvyozdnaya, T. M. (2012). Illegal International Migration: Causes and Dangers. Actual problems of state and law, 68, 179-184. http://nbuv.gov.ua/UJRN/apdp_2012_68_30

\section{ДОЛОННА ДЕРМАТОГЛІФІКА СУЧАСНИХ УКРАЇНЦІВ: РЕГІОНАЛЬНІ ТЕНДЕНЦІЇ}

\section{Гунас В. І., Мішалов В. Д., Серебреннікова О. А., Клімас Л. А., Шаюк А. В.}

Посилення світових міграційних процесів, що часто супроводжуються зростанням злочинності та ростом кількості невідомих осіб, зумовлюють необхідність у розширенні застосування методів непрямої ідентифрікації особи. На наш погляд, залучення дерматогліфрічного аналізу у випадках наявності непізнаних осіб допомогло б у справі судово-медичної ідентифікації етнотериторіальної належності невідомої особи. Мета роботи - виявити таксономічний комплекс ознак долонної дерматогліфріки локального рівня, які дозволяють диференціювати регіональну належність чоловіків України. Дослідження дерматогліфіки 400 практично здорових чоловіків із 5 адміністративно-територіальних регіонів України проведено за методикою Н. Ситтіпs Сh. $i$ Midlo. Cmaтистична обробка результатів проведена у пакеті "STATISTICA 6.1" з використанням непараметричних методів. Виявлена сукупність ознак долонної дерматогліфіки, що демонструють високий ступінь різнорідності між чоловіками з наступних адміністративно-територіальних регіонів країни: иентрального та східного (20,0\% показників), центрального та північного (16,9 \% показників), північного та західного (16,9 \% показників), західного та східного (15,38 \% показників) регіонів України. Чоловіки з північного і східного (6,2% показників), південного і західного (6,2 \% показника) та південного і східного (7,7 \% показників) регіонів України демонструють значну спорідненість за ознаками долонної дерматогліфіки. Загалом високу таксономічну цінність для внутрішньопопуляційної диференціації локального рівня мають: локалізація та насиченість долоні візерунками, розмір долонних кутів, наявність/відсутність додаткових вісьових трирадіусів, довжина відрізка с-t, індекс Каммінса. Ключові слова: долонна дерматогліфіка, чоловіки, адміністративно-територіальні регіони України, ідентифікація особи.

\section{ЛАДОННАЯ ДЕРМАТОГЛИФИКА СОВРЕМЕННЫХ УКРАИНЦЕВ: РЕГИОНАЛЬНЫЕ ТЕНДЕНЦИИ}

\section{Гунас В. И., Мишалов В. Д., Серебренникова О. А., Климас Л. А., Шаюк А. В.}

Усиление мировых миграционных процессов, часто сопровождающиеся ростом преступности и возрастающим количеством неизвестных лиц, обусловливают необходимость в расширении применения методов непрямой идентификации личности. На наш взгляд, привлечение дерматоглифического анализа в случаях наличия неопознанных лиц помогло бы в деле судебномедицинской идентификации этно-территориальной принадлежности неизвестного лица. Цель работы - выявить таксономический комплекс признаков ладонной дерматоглифики локального уровня, которые позволяют диффреренцировать региональную принадлежность мужчин Украины. Исследование дерматоглифики 400 практически здоровых мужчин с 5 административно-территориальных регионов Украины проведено по методике H. Cummins Ch. u Midlo. Cmamuстическая обработка результатов проведена в пакете "STATISTICA 6.1" с использованием непараметрических методов. Обнаружена совокупность признаков ладонной дерматоглифики, демонстрирующие высокую степень разнородности между мужчинами из следующих административно-территориальных регионов страны: центрального и восточного (20,0 \% показателей), центрального и северного (16,9 \% показателей), северного и западного (16,9 \% показателей), западного и восточного (15,4 \% показателей) регионов Украины. Мужчины с северного и восточного (6,2% показателей), южного и западного (6,2 \% показателя) и южного и восточного (7,7\% показателей) регионов Украины демонстрируют значительную однородность признаков ладонной дерматоглифики. В целом высокую таксономическую ценность для внутрипопуляционной дифрференциации локального уровня имеют: локализация и насыщенность ладони узорами, размер ладонных углов, наличие/отсутствие дополнительных осевых трирадиус, длина отрезка с-t, индекс Камминса.

Ключевые слова: ладонная дерматоглифика, мужчины, административно-территориальные регионы Украины, идентификация личности. 